\title{
ROLE HISTORIC ASSETS CAN PLAY IN REVIVING THE RETAIL HIGH STREET: A CASE STUDY OF DERBY'S RETAIL HIGH STREET
}

\author{
SARAH BALL, DAVID HIGGINS \& HAZEL ANN NASH \\ BTS, Birmingham City University, UK
}

\begin{abstract}
The long-term decline in the historic high street has been an important issue for local communities, governments and real estate investors. This has led to significant discussions concerning the triggers of retail decline and consideration for how heritage themed high streets can evolve in the future and the associated resources for this to be achieved. Utilising a case study of Derby's historical Cathedral Quarter, this paper explores (i) the issues involved in reversing the decline of retail in the traditional high street; (ii) the strategies used to sustain and improve the high street as a destination; and (iii) the role of heritage assets in improving business occupancy of high street premises. In order to provide an insight into the processes available to regenerate the high street and attract space occupiers, a series of semi-structured interviews were undertaken with leading real estate consultants and investment professionals. The research findings suggest there are multiple reasons for the decline, including economic, environmental, and functional factors, and that these will continue to impact the evolution of the high street moving forward, unless proactive strategies are put in place. Increased mixed-use development within town centres, including residential and co-working space, is seen by interviewees as significant. Furthermore, the case study provides clear evidence that utilising heritage assets with unique characteristics can positively impact the retail high street. This can include reinstating historical frontages of retail units and so strengthening visiting numbers that creates destination footfall, resulting not only in a decrease in vacancy rates but often improved rental values. A catalyst is to provide an informed strategy to those wishing to undertake projects similar to the funded regeneration works on the historical assets within Derby's Cathedral Quarter Scheme.
\end{abstract}

Keywords: high street, historic assets, retail operations, repurposing.

\section{INTRODUCTION}

Over the last few decades, the traditional functions of UK town centres and associated high streets have changed, with the focus shifting towards the expansion of out of town retail parks hosting a variety of outlets, including food, clothing and homeware goods [1]. With the rise of the online retail market and the ease of access to goods from it, people have been drawn away from town centres. Consequently, the character of the high street has continued to change, with retail spending declining in this sector, and this trend set to continue.

As high street retail faces these challenges, they need to consider how to approach changing consumer habits, rising business rates and the online retail market. Whilst consumers enjoy visiting local high streets, they are looking for an improved experience with many people preferring to combine shopping with other leisure activities, such as eating at fine dining restaurants [2]. The rising costs of conducting a business are also affecting the success of high street retail companies. Business rates and taxes can have a significant impact on small independent retailers, but even the larger retailers have been calling for the Government to review business rates in order to safeguard high street retail [3].

The most well-known and widely reported impact on high street retail has been the increase in the availability of online purchasing. Although a number of high street companies have adapted by having an online presence, it is the specialist 'online-only' retailers, such as Amazon and Asos, who are having the greatest impact on physical high street sales [4]. 
Facing these challenges, the redevelopment of historic high street locations continues to prove challenging in terms of providing a balance between commercial drivers and historical constraints. This research is based on a February 2020 case study of Derby's Cathedral Quarter, a prime example of a historic high street which has become an economic success in a time of widespread retail 'collapse.' The paper will examine how this quarter bucked the general trend of high streets and accomplished success in occupancy of high street premises.

This study adopted a qualitative approach, using carefully conducted, semi-structured interviews with six key professionals from the heritage, funding and retail industries. The interviewees included a funding consultant, a specialist from a funding provider, planning consultants, development consultants and a conservation officer from a local authority. The interviews maintained a clear focus, but with sufficient flexibility to allow for further discussion points. This enabled the participants to draw upon their own expertise and knowledge, in order to explore their opinions about the high street retail market and the redevelopment of the historical high street.

The following section provides a literature review covering the retail sector, key determinants and the high street regeneration with the focus on Derby's Cathedral Quarter. Section 3 will then set out the details concerning the selected methodology and associated details of interviewees. Section 4 provides the empirical findings and implications while the last section gives concluding comments.

\section{LITERATURE REVIEW}

In this section, the review of literature covers three key areas: the UK's current retail climate and key determinants, High Street regeneration and the Derby Cathedral Quarter.

\subsection{The UK's current retail climate and key determinants}

The UK retail market has been an increasing source of concern in recent years and, as such, is under constant scrutiny by today's media. Although it is generally recognised that the retail sector has been in a state of decline since the 1960s, it was not until 1995 onwards that solid statistics became available to support this. At this time the British Retail Consortium (BRC) was launched and began conducting research into the retail sector, analysing fast moving markets and long-term structural trends [5]. A further milestone, was the Hughes and Jackson [6] 'Death of the high street: identification, prevention reinvention' [6], research paper which identified the individual factors behind the changes in the retail sector with a conceptual model defining retail obsolescence with four key drivers (see Fig. 1).

Fig. 1 illustrates the multiple factors influencing the decline of the high street and the reasons for the general decline in the physical retail sector, and a real likelihood that the high street may well become obsolete as a retail location in the future. The key retail drivers for the demise of the high street are detailed as (i) Economic, (ii) Environmental, (iii) Functional, and (iv) Locational [6].

\subsection{1 (i) Economic}

Economic obsolescence arises as a result of changes in population, business innovation and, most importantly, market supply and demand. The biggest impact on supply and demand has been the rise of online shopping which, it is predicted, will account for approximately $20 \%$ of consumer expenditure by 2020 [7]. These figures are supported by the Office for National Statistics report for October 2019, which noted that, as a proportion of all retailing, online sales have increased to $19.2 \%$ [8], as online retail continues to create an easier retail experience for consumers. 


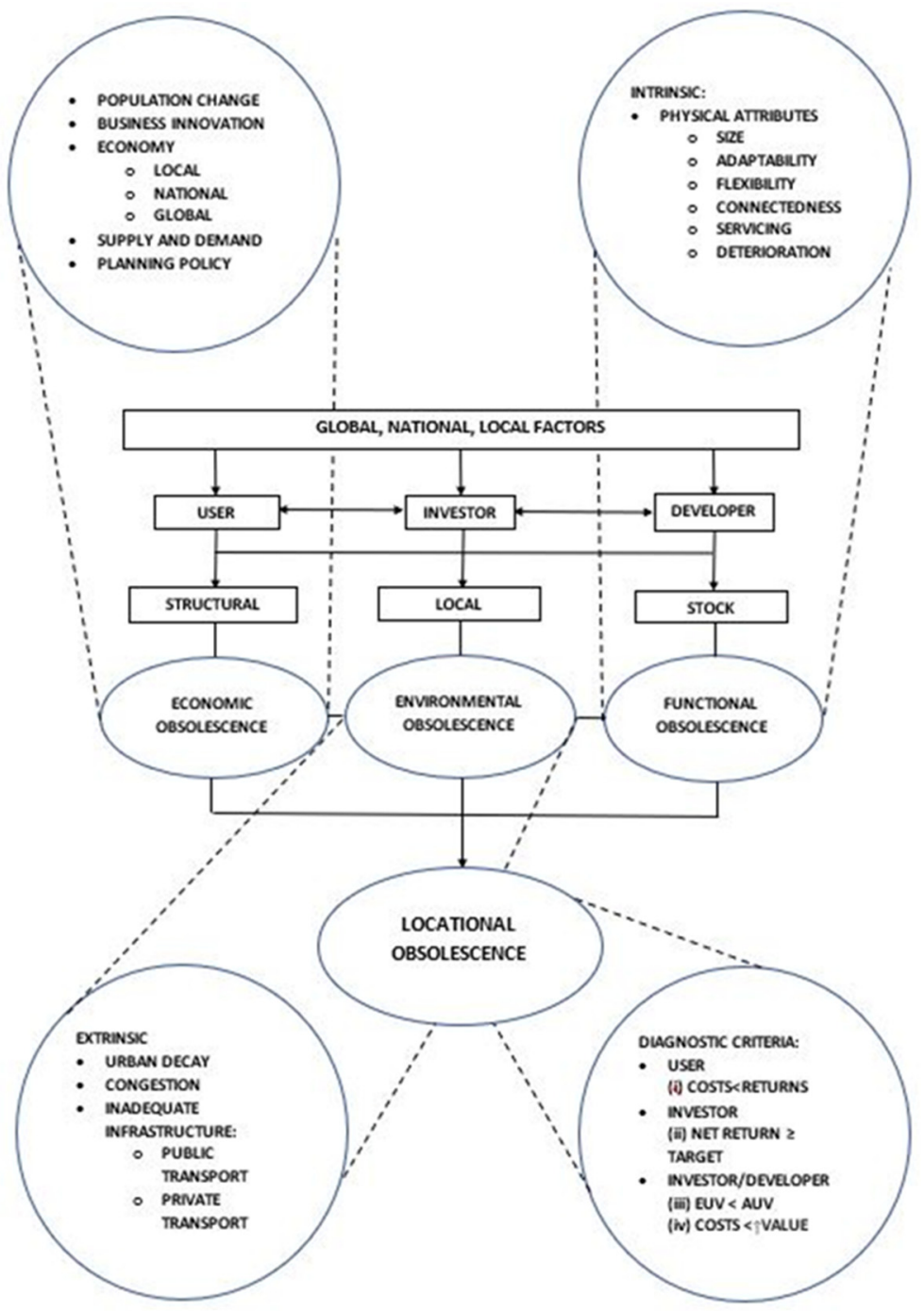

Figure 1: Conceptual model of retail obsolescence.

Part of the economic reasoning behind the changes in the retail market is that competition has arisen from other types of retail space, such as retail parks and supermarkets which offer more floor space than traditional high street shops, and are also able to adapt to changing circumstances, such as the ability to convert to warehousing and distribution uses. The creation of retail buildings with larger floor space, and consequently a wider range of goods, is creating a highly competitive atmosphere for retail outlets in towns and smaller cities [9].

\subsection{2 (ii) Environmental}

Although not intrinsic to the retail sector, the factors that contribute to environmental obsolescence (types of depreciation) are important if there is an increase in alternative retail destinations. Environmental aspects that impact the footfall of a retail location include urban 
decay and congestion, as a shopper is more likely to seek out a destination that is aesthetically pleasing and easy to get to [6]. This is supported by the RICS [10] examination of environmental factors, which highlights the fact that the current and future area around a retail property will have a significant impact on its continued use.

\subsection{3 (iii) Functional}

Functional obsolescence could be seen to arise from economic obsolescence. For example, technological changes can affect the qualities of a building, while social patterns can affect how a user interacts with a subject, in this case retail property [11]. Again, the RICS defines this as the process in which the specification of an asset no longer fulfils the function for which it was originally designed [10]. In terms of high street retail, many stores are able to function for retail purposes, but as those retail purposes are changing, the older high street stores are struggling to meet service and delivery area requirements and this will continue to change with the increased use of internet retail [12]. With physical challenges, operational changes and the speed at which retail is evolving, the requirement for high street retail space is declining.

\subsection{4 (iv) Locational}

The process of a location becoming obsolete is often depicted as gradual as the above three factors evolve and interact with each other, however certain circumstances may cause a location to become obsolete instantly. Locational obsolescence has been identified as a culmination of the previous three factors. In other words, if all of the above factors apply, then a specific retail property can be identified as 'locationally' obsolete within the retail sector, whether it is on a high street or elsewhere [6].

\subsection{High street regeneration}

To enable the high street to evolve, it is necessary to look for alternative ways to boost footfall, such as multi stakeholder involvement and funding. This involves changing the focus of the high street by introducing alternative uses such as office space and residential units. Mixed-use units are on the increase, combining the requirement for retail space alongside the suggested alternative uses. Conversion of retail space into other types of uses, particularly office space and residential units, is growing in popularity due to the increasing amount of vacant retail space on the high street. In previous years this focussed mainly on secondary retail space, however the possibility of changing the use of retail sites in areas where there is a concern that retail is no longer a viable use is increasingly under consideration [6].

Portas [13], proved to be a key piece of literature in terms of exploring the use of the high street. She identified the need for town centres to evolve rapidly in response to customer demands in order to remain relevant, however this has not been the case in most situations. Reinvention has tended to be a reactive response once the decline has already happened, rather than a pre-emptive action to head off a fall in the performance of the high street retail sector [14]. One possible solution would be to involve all stakeholders as early as possible, from retail management to the council, and even the public shoppers who ultimately will be supporting and using the environment. Initiatives such as NE1, a Business Improvement District Company focussed on strengthening Newcastle's economy, have had some success from implementing schemes such as free council parking after $5 \mathrm{pm}$ in order to attract people. This is also an example of a way of boosting the high street retail economy without having to physically introduce new development or alter the use of retail spaces [15]. 


\subsection{Derby's cathedral quarter: Historical and current}

Derby was originally a town with a small priory, with records dating back to the mid-12th Century. A hospital was added soon after, and it continued to expand in size and trade. Derby continued to grow throughout the 17th Century, with its economy based around brewing and cloth-making. Derby Cathedral has been highlighted as a reference point in Fig. 2. In 1839 the railway network reached Derby, aiding the continued growth of commerce in the area, and contributing to the Market Hall opening in 1866, the site of which is still used for this purpose today. The town's economy received a further boost in 1907 when Rolls Royce moved to Derby [16].

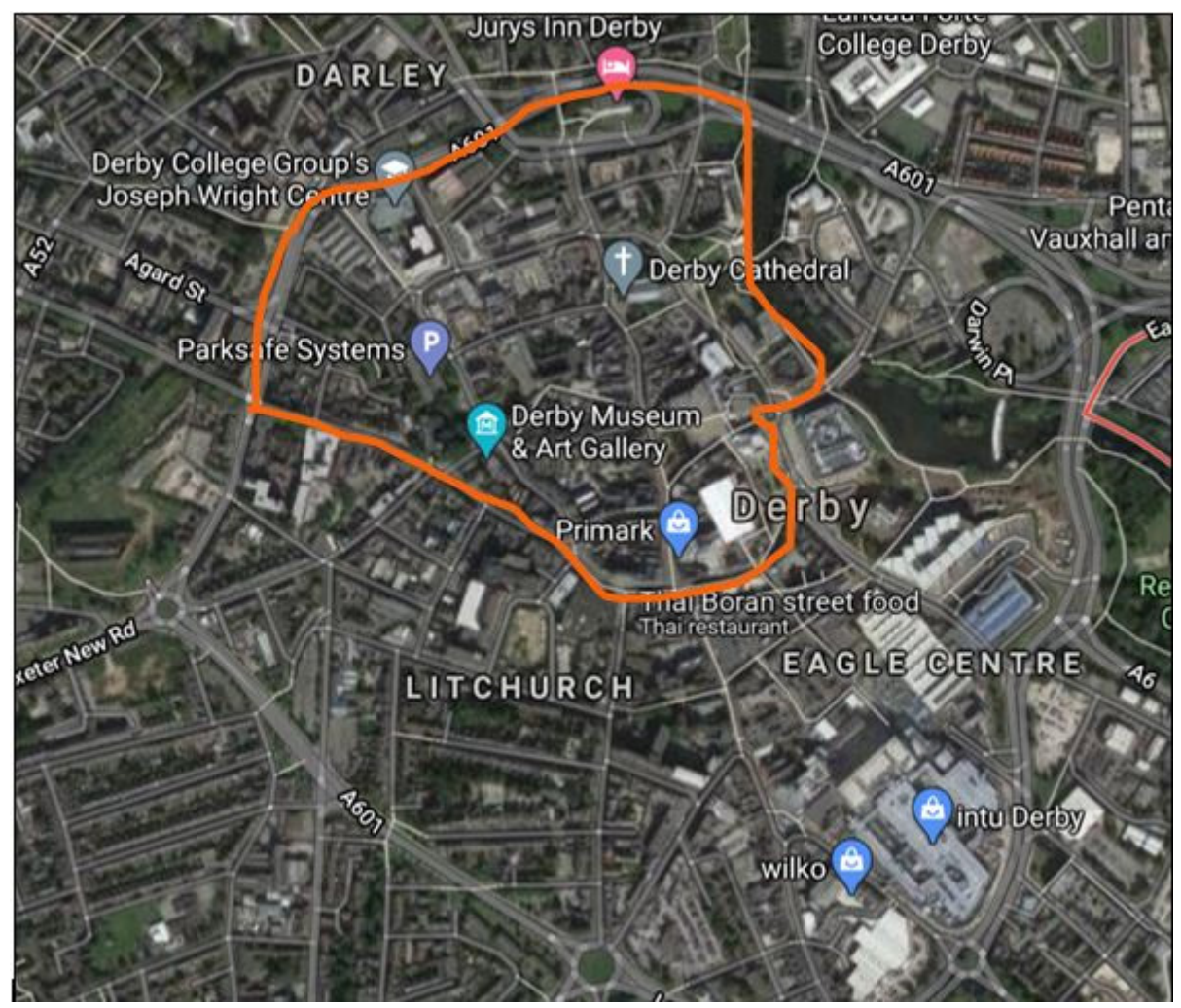

Figure 2: Map of Derby City Centre.

Derby's City Centre was once abundant with thriving high street shops. The Derby County Borough Directory dating back to 1935 holds a selection of advertisements for retail establishments that were flourishing in the area [17], however, since the opening of Westfield Derby in 2007 (the city's indoor shopping centre), many of the city centre's retail outlets have suffered, and consequently 2013 saw an increased number of units that were either boarded up or 'To Let.'

Fig. 2 shows the location of key Derby shopping precincts. The Derby Cathedral Quarter retail presence had initially been hit hard when the large Westfield Centre opened on the other side of the city centre. Colliers 2014 retail study noted that since the 2008 recession the 
cost of renting shop space had fallen by $22.2 \%$ ( $£ 40$ per square foot) over the five-year period into 2013 due to lack of confidence in the high street. However, at the time the East Midlands was faring better overall than other areas.

The Monitoring and Legacy Report summarising the project in DCQ stated that in the declining economic climate landlords' only response to the reduced demand for retail property was to reduce rents and introduce more flexible lease terms, neither of which is attractive in terms of a building's investment value. With the increase in poor quality and non-heritage frontage signs in a Conservation Area proving difficult for the council to control, it became clear that intervention would be required in order to restore the historic identity of the area. DCC attempted to combat this issue by producing guides for retailers applying for a change in shop front design, however this was not enough to have a significant impact on the damage that had been done.

A Partnership Scheme in Conservation Areas (PSiCA) between Historic England (HE) and Derby City Council (DCC) was set up between 2008 and 2016 following DCC's approach to HE regarding the worsening state of disrepair in Derby's conservation area. Following this, in $2009 \mathrm{HE}$ allocated a large proportion of the area as being 'at risk' of being lost due to decay, neglect or inappropriate development [18]. This wasn't however the first of the funding programmes to be put in place in Derby; in 2001 the Heritage Lottery Fund (HLF) and the Townscape Heritage Initiative (THI) had begun to provide aid through restorations of 16 properties in the area and improvements to the public realm, all of which were completed in 2018. Due to the success of this scheme, HLF has continued to aid the surrounding area.

DCC's approach to Historic England was partly led by HE's proven track record with grant-led regenerations in smaller towns, which demonstrated the potential for this to be applied to larger areas. The partnership was formed, and owners and leaseholders were approached regarding repairs and reinstatement of their shop frontages. At the same time the commercial benefits of a historical shop frontage reinstatement, such as increased footfall and sales were promoted, which led to an oversubscription of owners seeking assistance.

Once the project was completed and analysis had been undertaken, it became clear that the project had been a success. Quantitative footfall data was used to demonstrate the economic and social benefits of historic building regeneration. From 2008 to 2013 national footfall had decreased by $26 \%$ yet research conducted by Marketing Derby demonstrated that footfall in DCQ had increased by $12 \%$ and specifically, Sadler Gate's footfall had increased by $15 \%$, going against the national trend. This was supported by the fall in vacancy rates between 2010 and 2017, which in 2009 had been at 25\%, the highest of any major urban centre in the UK [19]. The above statistics are represented in Fig. 3 and a more detailed map of the Cathedral Quarter can be seen in Fig. 4.

Fig. 3 shows that funding is one way of aiding high street regeneration and has been used for this purpose for over thirty years. Although there are a variety of funds available to premises' owners, in most cases a portion of private funding is also required. However, it is important to note that without the opportunity to draw on funding many listed buildings and heritage assets would be neglected and fall into disrepair, resulting in a detrimental impact on the environmental, functional and locational characteristics of the high street. Ultimately the result would be a spiralling reduction in high street use.

The Derby's Cathedral Quarter case study offers a clear representation of the impact that funding aimed at repair and restoration of heritage assets can have in the successful regeneration not only of a single high street, but of an entire retail area. Furthermore, in physically improving the aesthetic appeal of historic buildings in the area, footfall and retail spending in a market that is otherwise generally declining has increased. 


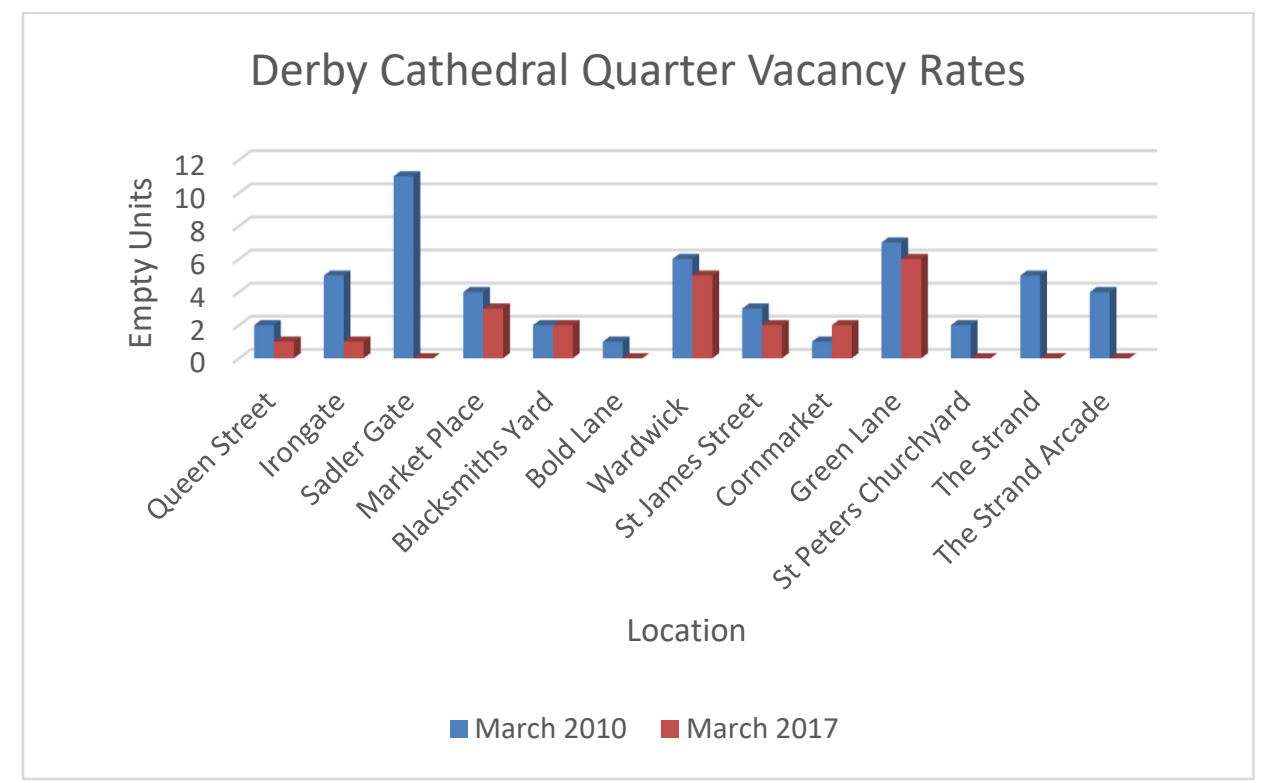

Figure 3: Derby cathedral quarter vacancy rates.

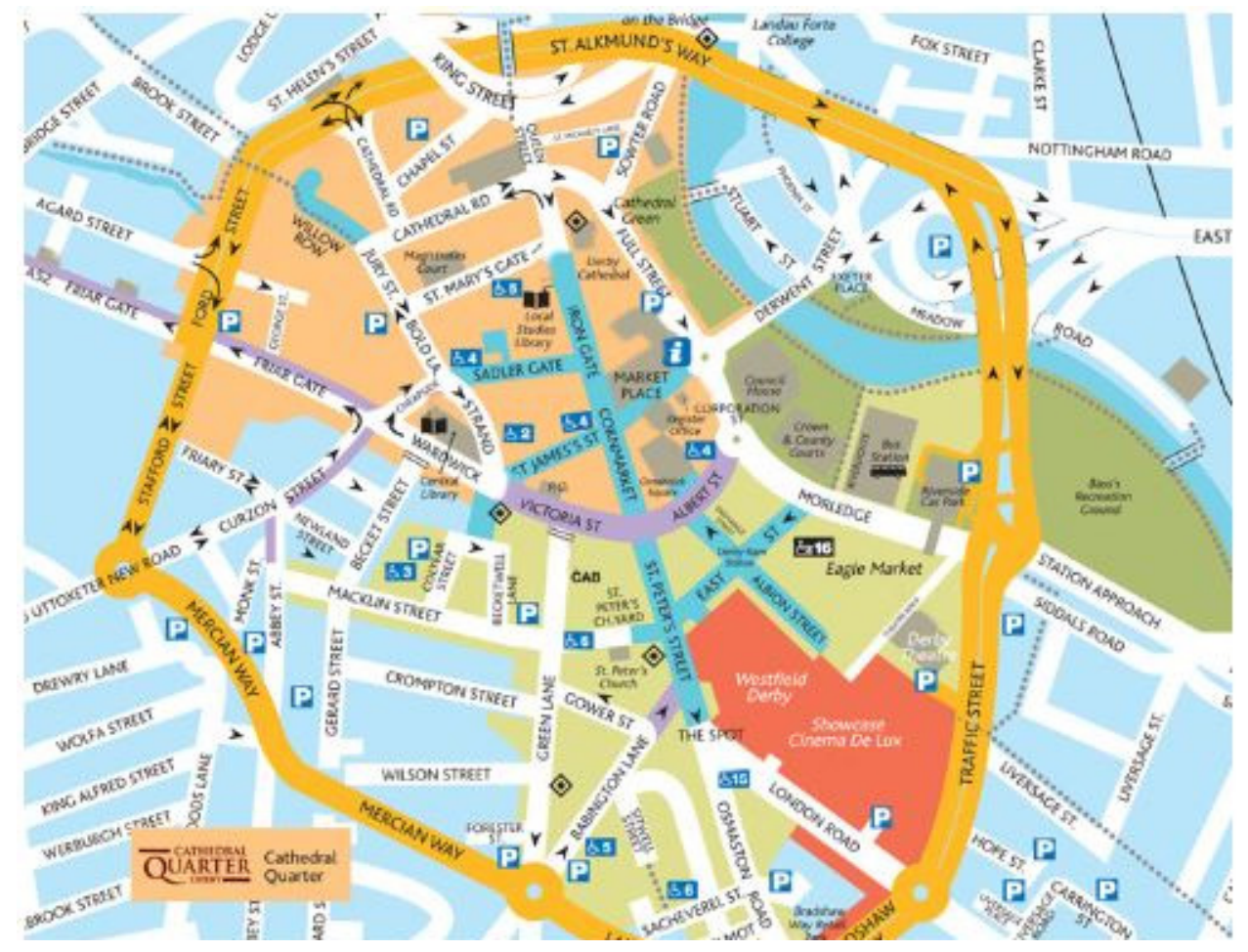

Figure 4: Derby cathedral quarter area map. 


\section{METHODOLOGY}

The research design has been formulated from responses given in six semi-structured interviews from a cross-section of leading property professionals with experience relevant to both the retail and funding sectors. The interviewees come from a wide variety of backgrounds, including funding consultants, funders, planning consultants, development consultants and local authorities. One of the funding bodies worked directly on the regeneration of Derby's Cathedral Quarter and other consultants have also carried out studies on Derby's retail market.

Table 1: Summary of interviewees.

\begin{tabular}{|c|c|}
\hline Interviewees & Background \\
\hline $\begin{array}{l}\text { Participant 1: } \\
\text { Conservation } \\
\text { Specialist }\end{array}$ & $\begin{array}{l}\text { - Principal Advisor and Lead Specialist for a funding provider } \\
\text { - Focus on conservation } \\
\text { - Focus on struggling towns and cities looking at development } \\
\text { and buildings }\end{array}$ \\
\hline $\begin{array}{l}\text { Participant 2: } \\
\text { Regeneration } \\
\text { Consultant }\end{array}$ & $\begin{array}{l}\text { - } \quad \text { Chartered Surveyor } \\
\text { - } \\
\text { Advises on development and regeneration projects across a } \\
\text { range of sectors including retail, mixed use and heritage }\end{array}$ \\
\hline $\begin{array}{l}\text { Participant 3: } \\
\text { Planning } \\
\text { Consultant }\end{array}$ & $\begin{array}{l}\text { - Chartered Town Planner } \\
\text { - Experience in planning permission for retail and commercial } \\
\text { proposals } \\
\text { - Undertakes retail and town centre studies } \\
\text { - Advises local authorities on retail matters }\end{array}$ \\
\hline $\begin{array}{l}\text { Participant 4: } \\
\text { Heritage } \\
\text { Consultant }\end{array}$ & $\begin{array}{l}\text { - } \quad \text { Chartered Surveyor } \\
\text { - Experience with grant funding, development and financial } \\
\text { viability, project management, procurement, and liaising with } \\
\text { funding providers }\end{array}$ \\
\hline $\begin{array}{l}\text { Participant 5: } \\
\text { Development } \\
\text { Consultant }\end{array}$ & $\begin{array}{ll}- & \text { Chartered Surveyor } \\
\text { - } & \text { Company Director of a specialist property development and } \\
\text { advisory company } \\
\text { - } \\
\text { Projects within multiple sectors including retail, leisure and } \\
\text { mixed use }\end{array}$ \\
\hline $\begin{array}{l}\text { Participant 6: } \\
\text { Conservation } \\
\text { Officer }\end{array}$ & $\begin{array}{l}\text { - } \quad \text { Conservation Officer at a local authority } \\
\text { - } \quad \text { Experience of working with Historic England on projects }\end{array}$ \\
\hline
\end{tabular}

Each interviewee consented to their participation by signing an informed consent letter and answered the guided interview questions either via a telephone or video interview. These questions were based on the learning objectives set out in the abstract and the broad topics defined within Section 2.

\section{RESULTS AND DISCUSSION}

There was an overwhelming consensus among the interviewees that the high street retail market has been in decline for a number of years, however opinions differed as to the causes of this decline, and what the current impacting factors are. All participants stated that the retail market has been impacted more since the financial crisis in 2008, but has been in a state of flux for the last 20 years. In the Regeneration Consultant's opinion, out of town retail has 
seen a 'cyclical movement'; it was prospering prior to the financial crisis and 'then the financial crisis decimated it, but then it remodelled itself and has succeeded.' This was supported by the Development Consultant, who stated that the introduction of 'discount retail parks, places where you get better value' from 2009, 'kept evolving' and 'the high street stagnated as it were.'

The Regeneration Consultant also stated that 'there is a control shift taking place' in terms of consumers' habits, and this accounts for the current decline. This view backs up the statistics suggesting that department stores were the only high street retailers to see a profit in late 2019 [20]. The Planning Consultant however, looked at the function of department stores in more detail, claiming that stores such as Debenhams and BHS were the 'anchor tenants' and that the increasing trend in the closure of these stores and their move away from the high street, particularly in the last five years, has played a major part in the decline in wider high street retail.

In considering the causes of the decline in the retail market, all the contributing factors mentioned by the interviewees can be categorised into the broad areas theorised by Hughes and Jackson [6].

\section{1 (i) Economic}

All the participants agreed that the introduction of online retail and increased exposure to the internet have played a role in the decline of high street retail with the Development Consultant stating that 'we discovered internet shopping and shopping habits changed,' and because of this, the Conservation Officer noticed that 'there have been more shops shutting over recent years.' However, both participants also believed that these issues are being overplayed. The Planning Consultant qualified this by stating that 'too much blame is put on the internet' as a sole cause of the decline, and there are other defining factors which should also be considered.

Both the Conservation Specialist and the Heritage Consultant were of the opinion that the closure of other uses within town centres is also contributing to the decline. For example, The Conservation Specialist explained that 'when the banks started shutting down, it meant that people didn't have a destination use to go to which they'd often combine with other shopping visits.' This view was supported by the Heritage Consultant, who raised the point that 'the closure of local civic buildings such as town halls, libraries and leisure centres meant that people had less of a reason to go to the town centres, making shopping trips a less frequent occurrence.' These arguments suggest that usage of the high street is changing, and that requirements for the kind of physical retail presence it offers are also altering, and this has had a significant impact on supply and demand [6].

Another economic factor, which was mentioned by all the participants, was planning policy, but in this regard opinion differed. The Planning Consultant believed that planning policy has not necessarily been a cause of the decline of the high street for retail purposes as a retail centre but stated that it would need to change in order to influence how high street retail would operate in the future. In terms of the decline, the Planning Consultant commented that

'... clearly it's a market failure and I think planning is an impediment to correct market failure ... I think sometimes it's overplayed as a factor ... yet the planning system needs to evolve at least to a certain degree.' (Planning Consultant) 
The Heritage Consultant was of the opinion that previous changes in planning policy had been a factor, as they had paved the way for the creation of larger out of town retail parks with destination retailers such as IKEA and supermarkets, and that this had led people away from the high street.

\section{2 (ii) Functional}

All the interviewees commented on the increase in vacancy rates, but it was agreed that this was not just down to an increasing number of businesses leaving retail units. The suitability of the space for the functional requirements of the businesses is also a factor. As such, the problem cannot just be attributed to business rates and taxes alone. Indeed, the Heritage Consultant focussed on the physical aspects of many high street retail units, which, when it comes to occupying high street retail units, often have:

'... difficult storage facilities, some of it might be upstairs, or it might be down a corridor or in a basement and you might not be able to get your lorries around the back very easily to load and unload. So, I think that's something retailers really have to think about.' (Heritage Consultant)

This view concurs with Grimsey et al. who state that the older stores in high street locations are struggling to meet service and delivery area requirements [12]. With larger retailers generally downsizing to smaller units or leasing less space altogether, larger units, which no longer suit the needs of businesses, are left empty. In other words, often the specification of an asset no longer fulfils the function for which it was originally designed [10].

\section{3 (iii) Environmental}

The Heritage Consultant expressed the importance of the 'actual physical environment of a high street, you know, it's a lot of pretty buildings. People might just go there for a day out, they might not go even to necessarily buy anything,' yet just being able to attract someone to a place will automatically increase the chances of retail sales. It was noted by the interviewees that a town centre's infrastructure will also have an effect on the success of its high street retail units. The Regeneration Consultant stressed the importance of providing good infrastructure and access links to a town centre to encourage people to come. There has been a marked increase in the number of people cycling and therefore better cycle access is required around town and city centres. This highlights the fact that a shopper is more likely to seek out a destination that is aesthetically pleasing and easy to reach [6].

\section{4 (iv) Location}

The Conservation Specialist focussed on the concept of placemaking as a whole, rather than planning alone, stating that there is

'... much more of an emphasis on placemaking rather than just development, and retail provisions, land use and planning and ... the way in which we think placemaking and provisional retail is having an input both positively and negatively over time depending on the place in question.' (Conservation Specialist) 
The concept of placemaking has been under discussion since the 1960s, however it gained more traction in the 1990s [21]. Placemaking is a process by which public spaces and buildings are shaped. It involves multiple factors, including planning and design, and requires input from a diverse range of people from professionals to residents of a local community, in order to bring improvements to a community from a cultural, economic, social and environmental perspective [22]. In terms of addressing the issue of retail in the high street, placemaking may prove to be a more suitable strategy for reviewing how the high street could be maintained by incorporating the wider aspects of community.

The Conservation Specialist expressed the view that even a small investment can have an impact, and

'... if people see the effect, they see the upward trend... and it attracts investment. When people see a downward trend, it actually inhibits it [investment].' (Conservation Specialist)

It would appear that the Conservation Specialist is correct, as the market report undertaken by Aspinall Verdi confirmed that the Cathedral Quarter in Derby was continuing to grow and benefit from new operators [23]. In the Derby PSiCA report this was described as a 'cluster effect' in which owners and leaseholders were approached and recognised the commercial benefits of reinstating a historical shop frontage, which led to an oversubscription of owners seeking assistance [19].

\section{SUMMARY}

The traditional retail high street has long been in decline and its future is a matter of contention among property professionals and the local community. More recently, it has become a more pressing issue, and it is widely accepted that urgent action will be required if we are not to lose the high street as a retail location altogether. In the past few years, a multitude of funding projects have been launched in a bid to breathe new life into the historic retail high street.

Given the limited amount of academic research on working solutions to the decline of the retail high street, this paper has drawn upon the findings of a case study of Derby's Cathedral Quarter, to demonstrate the impact funding and utilising heritage assets can have, and the opinions of a cross-section of Real Estate and Funding Professionals within the local area. The analysis was based around the Hughes and Jackson [6] conceptual model with economic, environmental, functional and locational categories.

The interviewees identified several economic factors, including the introduction of online retail which has a knock-on effect on other economic factors, such as supply and demand. The introduction and expansion of online retail has increased the accessibility of retail items and reduced the need for visiting the high street to make purchases. Consequently, this has reduced the stock requirements in stores, but increased the need for warehousing out of town, leading to the repurposing of high street locations for mixed uses and varied functions including office space and residential use. The change in consumer spending habits was also identified as a key economic reason for the reduction in high street spending. The majority of the interviewees commented that consumers are seeking multiple uses and an 'experience' from their local high street, and therefore shopping is no longer the primary reason for visiting town centres. Instead, shopping is seen as a secondary or tertiary reason for visiting them, and is often combined with eating out at restaurants, meeting friends, or going to the cinema.

The statistics from the PSiCA Report demonstrate the enormous impact the funding from Historic England, Derby City Council and private entities have had. All the major streets 
within the DCQ that underwent restorative works to their buildings experienced a decline in vacancy rates and an increase in footfall and rental values, which went against the national downward trend at the time. It is therefore evident that projects such as the one undertaken for Derby's Cathedral Quarter, which used funding as a resource to improve existing heritage assets, can continue to have a positive impact on the historic high street retail economy.

Overall, it was clear from the literature available and from the views expressed by the interviewees, that retail on the high street will continue to change and shrink and that this will increasingly open up the area to alternative uses such as office space and residential uses. However, retail will not disappear from the high street altogether if the location has an historic appeal and is aesthetically pleasing and offers shopping as a pleasurable activity.

\section{REFERENCES}

[1] Housing, Communities and Local Government, High Street and Town Centres in 2030, UK Parliament: London, 2019.

[2] Carmona, M., London's local high streets: The problems, potential and complexities of mixed street corridors. Progress in Planning, 100, pp. 1-84, 2015.

[3] Farrell, S., UK's business rates system "broken" says treasury committee. The Guardian, 2019.

[4] Butler, S., Thousands of UK shops left empty as high street crisis deepens. The Guardian, 2019.

[5] British Retail Consortium, About BRC, BRE: London, 2019.

[6] Hughes, C. \& Jackson, C., Death of the high street: Identification, prevention, reinvention. Regional Studies, Regional Science, 2(1), pp. 237-256, 2015.

[7] Colliers, Midsummer Retail Report 2011, Colliers: London, 2011.

[8] ONS, Retail sales, Great Britain: October 2019. Office for National Statistics, The Stationery Office, London, 2019.

[9] Carmona, M., de Magalhaes, C. \& Hammond, J., The Smaller Towns Report, BCSC: London, 2004.

[10] RICS, RICS Valuation - Professional Standards, Global and UK Edition, 8th edn, RICS: London, 2012.

[11] Williams, A.M., Obsolescence + Re-Use: A Study of Multi-Storey Industrial Buildings, School of Land and Building Studies, Leicester Polytechnic: Leicester, 1985.

[12] Grimsey, B. et al., The Grimsey Review: An Alternative Future for the High Street, Bill Grimsey, 2013.

[13] Portas, M., The Portas Review: An Independent Review into the Future of our High Streets, BIS: London, 2011.

[14] Pal, J., Ntounis, N. \& Theodoridis, C., How to reinvent the high street: Evidence from the HS2020. Journal of Place Management and Development, 10(4), pp. 380-381, 2017.

[15] Cape, S., Saving our high streets; With Christmas fast approaching, shops are working flat-out to encourage sales. But retail guru Mary Portas believes high streets need regeneration to save them from failure, find Stephen Cape. The Journal, 2011.

[16] Derby City Council, City Centre Conservation Area: Appraisal and Management Plan, Derby City Council: Derby, 2012.

[17] Johnson, R., The cost of renting retail space in Derby has fallen by almost a quarter over the past five years because of lack of confidence on the high street. Derby Telegraph, 2013.

[18] Historic England, What is the Heritage at Risk Programme? Historic England: Swindon, 2020. 
[19] Anarchitecture, Monitoring and Legacy Report: Derby PSiCA, Anarchitecture: Nottingham, 2017

[20] ONS, Retail sales, Great Britain: October 2019. Office for National Statistics, The Stationery Office, London, 2019.

[21] Project for Public Places, What is Placemaking? 2007.

[22] Historic England, Support for Place-Making and Design, Historic England: Swindon, 2020.

[23] Nexus Planning, Derby City Council, Retail and Centres Study, Nexus Planning: Manchester, 2019. 